\title{
COMBINING LANGUAGE AND CULTURE LEARNING IN TEACHER EDUCATION AT MARTIN LUTHER UNIVERSITY HALLE WITTENBERG
}

\author{
Peter Grüttner, Anne Julia Fett, \& Susanne Schütz \\ Center for Teacher Education, Martin Luther University Halle Wittenberg (Germany)
}

\begin{abstract}
At Halle's Martin Luther University the federally funded KALEI project is concentrating on future teachers' cultural assumptions and beliefs. In a two-fold approach it foresees on the one hand to increase the international mobility of students and on the other hand to develop a varied range of different courses to raise the students' intercultural awareness by explicitly combining language and culture learning. Within the almost exclusively mono-lingual German education system this is an innovative approach, which not only appreciates the various languages and their respective speakers but also acknowledges and underlines the emotional and symbolic component of languages and cultures.

Among the recently established courses is "Arabic in classrooms", which was set up in cooperation with the Institute for Oriental Studies. With a great number of Arabic-speaking pupils in schools, a course, that acquaints future teachers with the Arab language for classroom situations and provides knowledge on the history and cultures of the region, is very popular among students. The course ends with a certificate and is now a permanent part of the supplementary course program for our students wishing to become teachers.

Another innovative format combining language and culture aspects, open to prospective teachers of all subjects, is a number of sessions where students talk to international PhDs about their individual school experiences outside Germany. Every session goes by the tag-line "What school is like in ..." and features very personal insights into the cultural dimension of school, education and growing-up in another country.

In every-day school life language learning is not limited to the language classes. Teachers of all subjects have to have profound knowledge in the field of teaching German as a target language. The course "Teaching German as a target language" aims at facilitating students with the knowledge how teaching German along with the subject matter. With a multi-disciplinary team of lecturers with very diverse backgrounds (German Studies, Cultural Studies, Special Needs Education) the course deals with all questions of language learning, such as alphabetization, word formation, grammar, but also looks on the pupils' side addressing special needs, learning difficulties and psychological preconditions. Over the duration of the course every student will develop a learning material to be tested and employed in participating schools.

The accompanying research on all measures is addressing prospective teachers' cultural assumptions and beliefs. In particular, it is focusing on an increased intercultural awareness through situations of culture contact and cultural learning.

The oral presentation will focus on the measures, their content and range, the effect and on-going research.
\end{abstract}

Keywords: Teacher education, intercultural professionalisation, culture and language learning, German as a target language, cultural assumptions and beliefs.

\section{Introduction}

To deal with cultural and language diversity is considered to be one of the most important skills for prospective teachers, making it indispensable to culturally diversify teacher education. ${ }^{1}$

In Halle, the federal state of Saxony-Anhalt's teacher education for schools of general education is concentrated at the University's Center for Teacher Education (CTE, German: Zentrum für 
Lehrer*innenbildung, ZLB). It is responsible for about 3300 students in degree courses for all German school types.

The Center's team "Internationalisation of Teacher Education" has devised a dual approach, that foresees on the one hand to increase the international mobility of students ("Internationalisation Abroad") and on the other hand to develop a varied range of different courses ("Internationalisation At Home") to raise the students' intercultural awareness by explicitly combining language and culture learning. This is an innovative approach within the almost exclusively mono-lingual German education system, as it not only appreciates the various languages and their respective speakers but also acknowledges and underlines the emotional and symbolic component of languages and cultures. ${ }^{2}$

Figure 1. Project visualisation Internationalisation of Teacher Education.

\section{The Internationalisation Of Teacher Education}

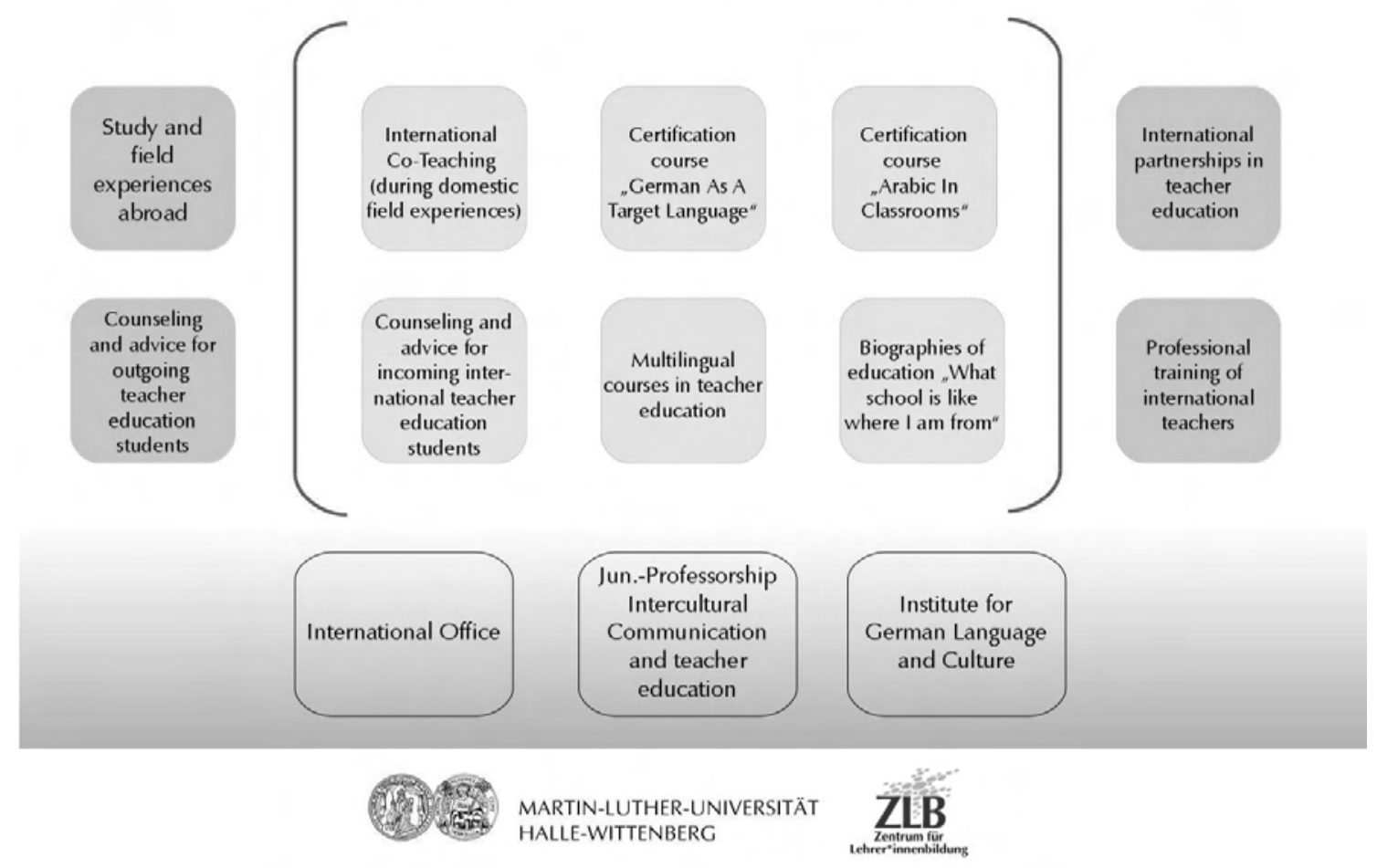

\section{Internationalisation abroad}

During the last decades, numbers of students engaged in international mobility have been very marginal at the universities involved in teacher education throughout Germany. ${ }^{3}$ Through focused advertisement for international mobility and information on funding possibilities, uniform recognition of stays abroad and the holistic coaching approach before, during and after field experiences abroad, numbers of students going abroad should be increased. At the University of Halle, the completion of various field experiences is an obligatory part of teacher education, thus opening most of these field experiences to be completed abroad was a logical decision. This kind of strategy was successfully implemented in collaboration with the Center's Office for Field Experiences. On the CTE's side work was required to strengthen ties with the Uni ‘s International Office and to reactivate existing international partnerships, also to gain new foreign pedagogical institutions as partners and to continuously foster co-operations with partner institutions worldwide. ${ }^{4}$ The result of these actions was an increase of more than $100 \%$ in international mobility for students.

\footnotetext{
${ }^{2}$ Cf. Dirim, İ. et al. (2015): Impulse für die Migrationsgesellschaft. Münster: Waxmann.

${ }^{3}$ For statistics on international student mobilty cf. Stifterverband (2015). Hochschul-Bildungs-Report 2020 Bericht 2015. Retrieved March 7, 2019, from https://www.stifterverband.org/hochschul-bildungs-report-2020-bericht-2015, 52-55.

${ }^{4}$ See for cooperations and activities: https://www.international.uni-halle.de/international_office/.
} 


\section{Internationalisation at home}

Aiming at complementary offers for intercultural professionalisation at the home institution, a second project area ${ }^{5}$ was established. It focuses on teaching offers that combine culture and language learning and expose students to different ideas of school and learning. The courses, lectures and learning elements are open to all students studying to become teachers in either German Gymnasia, secondary, primary schools or special needs education. Underlying is an approach of dual professionalisation ${ }^{6}-$ consisting of factual knowledge and experiential know-how -, that spans the different teaching formats:

- Certification course on language and culture learning ("Arabic In Classrooms")

- Supplementary course on learning and education in other cultures ("What school is like in ...")

- Certification course "Teaching German As A Target Language" for heterogeneous settings

\subsection{Arabic in classrooms}

Through our evaluations in teacher education we have found that a great number of teacher trainees feels poorly prepared for pedagogical actions in culturally diverse teaching and learning situations. On the one hand this is due to a lack of knowledge concerning the apparent multilingualism among pupils and on the other hand due to little experience in cross-cultural environments. Both results in a narrowing of the options for the individual teachers' professional actions. To address those shortcomings the CTE, in cooperation with Martin Luther University's Institute for Oriental Studies, has initiated a 40 hour certification course "Arabic In Classrooms". The course structure aims at providing students with a basic competence of Arabic (mostly listening and speaking and focused on the Syrian-Lebanese dialect as a prevalent and easily accessible variety). It also offers orientational knowledge regarding the languages and cultures of the Arab-speaking world. Conversations with immigrant and displaced pupils from German schools stimulate a change in perspective and further increase the learning yield. The course is held by Arabic native speakers that have a distinct teaching profile in higher education. "Arabic In Classrooms" has proven to be very popular among teacher education students and is being offered once per semester. The course's format is easily transferable to other languages and a similar course focusing on Farsi is in development.

\subsection{What school is like in ...}

In order to initiate a personal engagement and individual insights into the cultural dimensions of school, education and growing up in another country, a new supplementary course has been established. This course goes by the tag-line "What school is like in my country" and opens a dialogue between prospective teachers and international $\mathrm{PhDs}$ and researchers from abroad. It functions in the form of a biographical interview between students and the speaker, who gives otherwise neutral figures and numbers a human face. We ask our guests to talk about their personal school experiences, growing up and generally being a young person in another country outside Germany. By now, relatively young speakers (25 to 38 years) from countries such as Albania, Benin, Brazil, Cameroon, Colombia, Kenya, Lebanon, Peru, Serbia and Syria have contributed. They can be referred to as peers for students - which represents a decisive trait of our course concept, based on the positive link between knowledge acquisition and the formation of affectionate relations. ${ }^{7}$

With the intent to share parts of the format with a broader public and to adapt it to new target groups (such as teacher educators and in-service teachers), we also have conducted guided video interviews with all of our speakers. Interview questions focus on beliefs and attitudes towards education and learning outside Germany. In the research process, findings will be contrasted by using the documentary method. ${ }^{8}$

\subsection{Teaching German as a target language}

In school life language acquisition and language learning extend beyond language classes ${ }^{9}$. Of course, tomorrow's teaching staff needs to have extensive knowledge on the German language and its appropriate use throughout all subjects. Thus, in first place, this course grants all students the linguistics

\footnotetext{
${ }^{5}$ Inner boxes, framed by the parenthesis.

${ }^{6}$ Cf. Oevermann, U. (1996). Theoretische Skizze einer revidierten Theorie professionellen Handelns. In A. Combe \& W. Helsper (Eds.), Pädagogische Professionalität (70-183). Frankfurt a.M.: Suhrkamp.

7 Stürmer. S. (2008). Die Kontakthypothese. In L.-E. Petersen \& B. Six, Stereotype, Vorurteile und soziale Diskriminierung (283-291). Weinheim: Beltz.

${ }^{8}$ Cf. Bohnsack, R. (2011). Qualitative Bild- und Videointerpretation: Die dokumentarische Methode. Stuttgart: UTB 2011.

${ }^{9}$ Cf. Ahrenholz, B. \& Oomen-Welke, I. (2017). Deutsch als Zweitsprache. Hohengehren: Schneider.
} 
and methodology necessary to teach German along the subject matter. ${ }^{10}$ However, beyond this, factual knowledge in several different other fields is required:

(1) Psychological preconditions and special needs education,

(2) Cross-cultural mediation in schools,

(3) (Re-)design of learning materials.

An innovative feature is the inclusion of University staff from different faculties (such as German Studies, psychology and sociology), who cooperate with the Center for Teacher Education (responsible for the part on cross-cultural mediation). All lecturers have hands-on experience in teaching pupils with migration background in different schools. The course schedule foresees a kick-off meeting to be held in a school and with the different teachers being present. It is the chance for students to engage in a discussion and get a first idea of the challenges ahead and the nature of the learning material that is asked to be designed or created. Most of the sessions are held as evening or full-day workshops on the weekend. The closing event features a teaching material exchange of the GATL-materials ${ }^{11}$ that our students have developed and that were tested by them, some teachers and pupils from our partner institutions.

\section{Conclusion}

The underlying concept of the Internationalisation of Teacher Education as designed by the CTE aims to increase intercultural awareness through situations of culture contact and cultural learning. It blends language and culture learning in order to offer an effective means to counter the (still) prevalent monolingualism in the German education system.

The accompanying research on all activities addresses prospective teachers' cultural assumptions and beliefs, which are crucial for their future pedagogical actions as multipliers in a plural, globally networked society ${ }^{12}$. The ideal of school mirroring the open society, which can only be fulfilled through these kind of multipliers, becomes increasingly important in today's Europe with its tendencies towards exclusive and populist agendas. In this complex situation, institutions of teacher education more than ever carry the responsibility to constantly motivate students and ultimately teachers-to-be to appreciate cultural heterogeneity.

\section{References}

Ahrenholz, B. \& Oomen-Welke, I. (2017). Deutsch als Zweitsprache. Hohengehren: Schneider.

Bohl, T. et al. (2017). Umgang mit Heterogenität in Schule und Unterricht. Grundlagentheoretische Beiträge und didaktische Reflexionen. Bad Heilbrunn: Verlag Julius Klinkhardt.

Bohnsack, R. (2011). Qualitative Bild- und Videointerpretation: Die dokumentarische Methode. Stuttgart: UTB 2011.

Dirim, İ. et al. (2015): Impulse für die Migrationsgesellschaft. Münster: Waxmann.

Kultusministerkonferenz (2013). Interkulturelle Bildung und Erziehung in der Schule. Retrieved March 7, 2019, from https://www.kmk.org/fileadmin/Dateien/pdf/Themen/Kultur/1996_10_25Interkulturelle-Bildung.pdf.

Lütke, B. et al. (2017). Fachintegrierte Sprachbildung: Forschung, Theoriebildung und Konzepte für die Unterrichtspraxis. Berlin/New York: De Gruyter.

Oevermann, U. (1996). Theoretische Skizze einer revidierten Theorie professionellen Handelns. In A Combe \& W. Helsper (Eds.), Pädagogische Professionalität (70-183). Frankfurt a.M.: Suhrkamp.

Stifterverband (2015). Hochschul-Bildungs-Report 2020 - Bericht 2015. Retrieved March 7, 2019, from https://www.stifterverband.org/hochschul-bildungs-report-2020-bericht-2015.

Stürmer. S. (2008). Die Kontakthypothese. In L.-E. Petersen \& B. Six, Stereotype, Vorurteile und soziale Diskriminierung (283-291). Weinheim: Beltz.

\footnotetext{
${ }^{10}$ Cf. Lütke, B. et al. (2017). Fachintegrierte Sprachbildung: Forschung, Theoriebildung und Konzepte für die Unterrichtspraxis. Berlin/New York: De Gruyter.

${ }^{11}$ To access all materials of past courses see: https://cloud.uni-halle.de/index.php/s/XWXg7coJ9SnBPBw.

12 Kultusministerkonferenz (2013). Interkulturelle Bildung und Erziehung in der Schule. Retrieved March 7, 2019, from https://www.kmk.org/fileadmin/Dateien/pdf/Themen/Kultur/1996_10_25-Interkulturelle-Bildung.pdf, 2.
} 